This is an Open Access article distributed under the terms of the Creative Commons Attribution 4.0 International License.

ORIGINAL ARTICLE

\title{
THE EFFECT OF HEALTH PROMOTION USING LEAFLETS AND AUDIO-VISUAL ON IMPROVING KNOWLEDGE AND ATTITUDE TOWARD THE DANGER OF HIV/AIDS AMONG ADOLESCENTS
}

\author{
Yafrinal Siregar' ${ }^{1}$ Kintoko Rochadi ${ }^{2}$, Namora Lubis ${ }^{2}$ \\ 1 Student of Masters of Public Health, Universitas Sumatera Utara, \\ 2 Lecturer of Faculty of Public Health, Universitas Sumatera Utara, Prof. Maas Street, \\ University of North Sumatera, Medan, Indonesia \\ * Correspondence: yafrinalsiregar@Gmail.com
}

\begin{abstract}
:
HIV / AIDS in adolescents cannot be separated from social changes and harmful lifestyles such as premarital sex, constantly changing sex partners, and drug abuse. The study aimed to examine the effect of health promotion using leaflets and audio-visual on adolescents' knowledge and attitude toward the danger of HIV/AIDS at SMK Swasta Imelda, Medan. Using the Wilcoxon test tested the hypothesis. The result of the research showed that there was a significant influence of leaflet and audio-visual media $(p<0.05)$ on adolescents' knowledge and attitude in the post-intervention. The conclusion was that leaflet, and audio-visual media were more effective in increasing adolescents' knowledge and attitude toward the danger of HIV/AIDS. It is recommended that parents control their children democratically at home or outside their homes. The school management should increase the cooperation with parents to increase students' academic development, and the health care providers in the neighborhood should increase health education program.
\end{abstract}

Keywords: leaflet, audio-visual, knowledge, attitude, the danger of HIV/AIDS

International Journal of Nursing and Health Services (IJNHS), September 2019, Volume 2, Issue 3; Page 172-179

Received: 27 June 2019; Revised: 19 July 2019; Accepted: 23 July 2019

DOI: http//doi.org/10.35654/ijnhs.v2i3.213

\section{Introduction}

HIV / AIDS is a health problem in the world since 1981; this disease develops in a pandemic. This problem can result in losses not only in the health sector but also in the social, economic, political, cultural, and demographic sectors (1).

World Health Organization (WHO) reported that 3.5 million people in Southeast Asia are living with HIV / AIDS in 2011. However, several countries, such as Myanmar, Nepal, and Thailand, show a declining trend of new HIV infections. This is due to the successful implementation of the HIV / AIDS prevention program through the Condom Use program. The trend of deaths caused by AIDS between 2001 and 2010 is different in every 
part of the country. In Eastern Europe and Central Asia, several people died of AIDS increased from 7,800 to 90,000, in the Middle East and North Africa rising from 22,000 to 35,000 , in East Asia also rising from 24,000 to 56,000 (2)

Indonesia is one of the countries that experience the highest increase in cases. At the end of 1996, 501 people had HIV / AIDS cases, 119 had AIDS, and 382 had HIV + status (3).

The number of cases that occurred in Indonesia until the end of December 2008 had reached 16,110 cases of AIDS and 6,554 cases of HIV, while the number of deaths due to AIDS was recorded at 3,362 people. Of all people living with AIDS, 12,061 patients were men with the highest spread through sex (3). The increase in HIV / AIDS has risen so sharply. In 2015, the number of HIV cases increased dramatically from 3,594 cases in 2014 to 5,184 AIDS cases and cases totaling 5,625 cases in 2014 to 5,660 cases in 2015. Of the 10,844 HIV / AIDS sufferers in 2015, those eligible for ARV treatment were 7,518 patients and 6,233 patients who received ARVs or 83\%. The percentage of PLWHA getting ARVs has increased when compared to the achievement of 2014 which is $79 \%$, this is due to the addition of PDP services (Care, Support and Treatment) in some Kab./Kota.

North Sumatra is ranked 8th out of 33 provinces in Indonesia with 700 AIDS cases. Medan is a city that has the highest prevalence of AIDS in North Sumatra as many as 430 cases. HIV and AIDS prevention behavior in adolescents is very dependent on the level of knowledge. The results of previous studies show that action based on experience lasts longer than the practice that is not based on knowledge. Education has an essential role in determining human quality, with human education will gain understanding and information. The higher the level of education of a person, the higher the quality of life (4).

Last year, an increase in HIV / AIDS increased so sharply. In 2015, the number of HIV cases significantly increased from 3,594 cases in 2014 to 5,184 AIDS cases and cases totaling 5,625 cases in 2014 to 5,660 cases in 2015. Of the 10,844 HIV / AIDS sufferers in 2015, those eligible for ARV treatment were 7,518 patients and 6,233 patients who received ARVs or $83 \%$. The percentage of PLWHA getting ARVs has increased when compared to the achievement of 2014 which is $79 \%$, this is due to the addition of PDP services (Care, Support and Treatment) in some Kab./Kota.

North Sumatra is ranked 8th out of 33 provinces in Indonesia with 700 AIDS cases. Medan is a city that has the highest prevalence of AIDS in North Sumatra as many as 430 cases. HIV and AIDS prevention behavior in adolescents is very dependent on the level of knowledge. The results of previous studies show that behavior based on knowledge lasts longer than behavior that is not based on knowledge. Education has an essential role in determining human quality, with human education will gain understanding and information. The higher the level of education of a person, the higher the quality of life (5).

Socialization and counseling efforts about HIV / AIDS transmission behavior are significant to increase adolescent knowledge, change behavior, and increase growing awareness. Media Health Promotion as an external factor can be used to improve learning efficiency because it has the potential or ability to stimulates the learning process (6).

Leaflet media is a medium commonly used in teaching and learning activities in Indonesia. Leaflet media is also a teaching aid that is often used in public health promotion activities. The low reading interest encourages renewal efforts in utilizing leaflet media to 
increase knowledge (7). Besides Leaflets, the use of audiovisuals is also useful for conveying important information (8).

Adolescents as targets of health promotion on HIV / AIDS are based on the assumption that psychologically the characteristics of adolescent personality are unstable. Therefore to change the wrong perception about HIV / AIDS needs to be prevented by providing information about the dangers of HIV / AIDS. Based on a preliminary survey with several students at Medan's Private Vocational School. The author obtained information that many of these students still did not know the dangers and transmission of HIV / AIDS. Also based on the statement from the school for five years recently, there was no counseling about HIV / AIDS in schools.

\section{Objective}

The study aimed to examine the effect of the health promotion-based leaflets and audiovisual media on Improving the Knowledge and Attitude Toward the Danger of HIV/AIDS among adolescents

\section{Method}

The purpose of the study was to analyze the influence of audiovisual media and leaflets on the level of knowledge and attitudes of adolescents about the dangers of HIV / AIDS in Imelda Private Vocational Schools. This study uses a quasi-experimental method (Quasi Experiment), with the research design one group pre-test and post-test to determine the effect of the use of leaflet and audiovisual media on the level of knowledge and attitudes of adolescents about the dangers of HIV / AIDS. The design of this study the treatment group acts as a control over itself

This design is used to compare the results of measurements before and after treatment in the two groups, in the field or community research, where researchers cannot or are difficult to control perfect as in right design experiments

The study population was all students SMK Imelda Medan, totaling 112 students. With a total sample of 53 students. Intervention with audiovisual and leaflet media was done one time in interventions groups after two weeks then posttest was done. Data collection was carried out before and after the intervention, directly from respondents based on knowledge and attitude questionnaires. 


\section{Result}

\subsection{Distribution of characteristics of adolescent in SMK Imelda Medan ( $n=53)$}

Table 1. Distribution of characteristics of Adolescent in SMK Imelda Medan

\begin{tabular}{lcc}
\hline Characteristics & F & \% \\
\hline Age & 5 & 9,4 \\
13 & 8 & 15,1 \\
14 & 25 & 47,2 \\
15 & 7 & 13,2 \\
16 & 1 & 1,9 \\
17 & 7 & 13,2 \\
18 & & \\
Sex & 20 & 37,7 \\
Male & & 62,3 \\
Female & 33 & \\
& & \\
Source Information obtained about & HIV/AIDS & 56,6 \\
Television & 30 & 17,0 \\
Radio & 9 & 13,2 \\
Newspaper & 7 & 7,5 \\
Health Worker & 4 & 5,7 \\
Others & 3 & \\
\hline
\end{tabular}

\subsection{Distribution of respondents based on knowledge before and after receiving intervention}

Table 2. Shows have given intervention with leaflet and audiovisual media, the majority of respondents were knowledgeable enough (79.2\%), and after being given intervention, the majority of respondents were well informed $(60.4 \%)$

\begin{tabular}{lcccc}
\hline \multirow{2}{*}{ Knowledge } & \multicolumn{2}{c}{ Before } & \multicolumn{3}{c}{ After } \\
\cline { 2 - 5 } & $\mathbf{f}$ & $\mathbf{\%}$ & $\mathbf{f}$ & $\mathbf{\%}$ \\
\hline Good & 2 & 3,8 & 32 & 60,4 \\
Enough & 42 & 79,2 & 21 & 39,6 \\
Less & 9 & 17 & 0 & 0 \\
\hline Total & $\mathbf{5 3}$ & $\mathbf{1 0 0}$ & & \\
\hline
\end{tabular}




\subsection{Frequency of respondents based on attitude before and after receiving Intervention}

Table 3. Frequency of respondents based on attitude before and after Intervention

\begin{tabular}{lcccc}
\hline \multirow{2}{*}{ Attitude } & \multicolumn{2}{c}{ Before } & \multicolumn{2}{c}{ After } \\
\cline { 2 - 5 } & f & $\mathbf{\%}$ & f & \% \\
\hline Good & 3 & 5,7 & 32 & 60,4 \\
Enough & 42 & 79,2 & 21 & 39,6 \\
Less & 8 & 15,1 & 0 & 0 \\
\hline Total & $\mathbf{5 3}$ & $\mathbf{1 0 0}$ & $\mathbf{5 3}$ & $\mathbf{1 0 0}$ \\
\hline
\end{tabular}

\subsection{Frequency Distribution of Adolescent Knowledge Based on Mean value Before and after Intervention}

Table 4. Distribution of adolescent knowledge based on the mean value before and after receiving Intervention

\begin{tabular}{lccc}
\hline & $\mathrm{N}$ & Mean & SD \\
\hline Before & 53 & 12.58 & 3.450 \\
After & 53 & 17.74 & 2.588 \\
\hline
\end{tabular}

Table 4 showed the mean of knowledge before receiving intervention with leaflet and audiovisual media 12.58 with a standard deviation of 3,450, and after being given intervention, the average (mean) knowledge of respondents is 17.74 with a standard deviation of 2,588

\subsection{Distribution of adolescent attitude based on mean value before and after receiving the intervention}

Table 5. Distribution of adolescent attitude based on mean value before and after receiving the Intervention

\begin{tabular}{lccc}
\hline & N & Mean & SD \\
\hline Before & 53 & 17,56 & 3,271 \\
\hline After & 53 & 18,13 & 4,792 \\
\hline
\end{tabular}

Table 5 shows the mean (mean) attitude before being given intervention with leaflet and audiovisual media 17.56 with a standard deviation of 3.271 , and after being given an 
intervention, the average (mean) attitude of respondents was 18.13 with a standard deviation of 4.792 .

\subsection{Different mean score of knowledge and attitude of adolescent before and after receiving intervention}

Table 6. Different Average Score of Knowledge and Attitude of adolescent Before and After being given the intervention

\begin{tabular}{llccc}
\hline \multirow{2}{*}{ No } & variable & \multicolumn{2}{c}{ Mean Rank } & value P \\
\cline { 3 - 5 } & & Before & After & \\
\hline 1 & Knowledge & 0,00 & 11,00 & 0,001 \\
\hline 2 & Attitude & 0,00 & 7,00 & 0,001 \\
\hline
\end{tabular}

Table 6 showed the mean difference between before and after intervention with leaflet and audiovisual media on knowledge. The results showed a positive effect of knowledge with mean rank> 10; $p<0.05$ ), and their attitudes (difference in mean rank $<10 ; p<0.05$ )

\section{Discussion}

The Influence of Health Promotion Media for Leaflets and Audio Visual on the Level of Youth Knowledge and Attitudes About the Dangers of HIV / AIDS

Based on the results of research on adolescents before and after being given intervention with leaflet and audiovisual media about the dangers of HIV / AIDS showed differences in the mean rank knowledge value of 0.00 before the intervention and the mean rank value of 11.00 after the intervention $(p=0.001$ or $p<0,05)$ with a mean rank difference> 10. Based on the statistical significance shows, there are differences in knowledge before and after being given intervention in adolescents.

This is consistent with the theory that health education is a dynamic process of behavior change to change or influence human behavior that includes a component of knowledge, attitude, or practice(7).

The results of this study are not in line with previous studies which stated there was no relationship between health education and the level of adolescent knowledge. The results of the test obtained the value of Sig. amounting to $0.051(\mathrm{p}<0.05)$, this shows that there is no significant difference in the knowledge of respondents between before and after being given intervention (11)

The results of this study were supported by previous studies conducted by Rismawati, which discussed whether or not the Effect of Health Counseling on Youth Knowledge and Attitude in 2012. 
Other results showed that there were influences from the leaflets and audiovisual media about the knowledge and attitudes of adolescents before and after receiving the intervention (9).

From these results, the researchers assume that this change is caused because the educational model provided can help patients more easily understand what is taught. Besides the use of media aids can make it easier for patients to digest the material obtained (12). Heinich (1982) suggests that the media are intermediaries that offer information between sources to recipients (13). Messages, ideas, ideas, or information conveyed by the teacher or speaker will be readily accepted if given with correct and useful methods and media.

Whereas in the attitude, based on the results of research on adolescents before and after being given intervention with leaflet and audiovisual media about the dangers of HIV / AIDS showed differences in the mean rank attitudes of 0.00 intervention and mean rank of 7.00 after intervention ( $p=0.001$ or $p<0.05$ ) with the mean rank difference $<10$. Based on the statistical value shows, there are differences in attitudes before and after being given intervention (14).

The results of this study are in line with previous research showed there is no significant difference in the attitudes among adolescents between experimental and control group after receiving the audiovisual media. (15). Most adolescents have less attitude about efforts to prevent sexually transmitted infections. Researchers assume that adolescents are more knowledgeable about the dangers of HIV / AIDS so they can also have the right attitude towards the risks of HIV / AIDS.

\section{Conclusions}

In conclusion, there is a positive effect of health promotion using leaflets and audiovisual on improving knowledge and attitude toward the danger of HIV/AIDS among adolescents

\section{References}

(1) Kusuma H. Relationship Between Depression and Family Support with Quality of Life of HIV / AIDS Patients Undergoing Care at RSUPN Cipto Mangunkusumo Jakarta. 2010

(2) Ministry of Health, Republic of Indonesia. The basic health research report". Jakarta: Data and Information Center. 2013.

(3) Muninjaya AA. Three ways to prevent AIDS. In: AIDS in Indonesia: Problems and Management Policies. Jakarta: Penerbit Buku Kedokteran EGC. 2008

(4) Effendy F, Makhfudli. Community health nursing Jakarta: Salemba Medika. 2009

(5) Benita, NR. The effect of counseling on the level of reproductive health knowledge in adolescent junior high school students. Semarang: University of Palembang. 2012

(6) Nurhidayah, Rika E. Behavioral Science and Health Education for Nurses. Medan: USU Press. 2010

(7) Notoatmodjo, Soekidjo. Concepts of Health Behavior and Behavior. In: Education and Health Behavior. Jakarta: PT Rineka Cipta. 2012. 
(8) Taufiq, Ahmad. Effectiveness of Leaflet Media and Brochure Media Against Increased Knowledge and Attitudes of Patients in the Treatment of Diabetes Mellitus in RSUD Dr. R. M Djoelham Binjai 2015. Universitas Sumatera Utara Press. 2015

(9) Rismawati. Effects of Health Education on Adolescent Knowledge and Attitudes About Drugs in SMA Negeri 1 Baraka, Enrekang Regency. 2012

(10) Boon H, Ruiter RAC, James S, Bone BVD, Williams ERP. The Impact of a Communitybased Pilot Health Education Intervention for Order People as Caregivers of Orphaned and Sick Children as a result of HIV and AIDS in South Africa. J Cross Cult Gerontol, 2009; 24:373-389.

(11) Septiana. Effect of Health Education on Adolescent Knowledge Levels on Reproductive Health in Ruhama Ciputat Islamic Middle School. 2014

(12) Mubarak. Health Promotion and Behavioral Sciences. Jakarta: Rineka Cipta. 2007

(13) Setiawati. Health Education: Trans Info Media. 2008

(14) Shamsideen SA. Impact of Audio-Visual Materials in The Dissemination of Knowledge for Facilitators in Some Selected Literacy Centres in Oshodi/Isolo Local. 2016

(15) Yanti ED, Dewi YI, Nurcahayati S. Effects of Health Education Using Audio-Visual Media on Knowledge and Attitudes. 2015 